\title{
Disparities in Access to Neurologic Telemedicine During the COVID-19 Pandemic
}

\author{
A Bronx Tale
}

Jonathan M. Gursky, MD, Alex Boro, MD, Sheri Escalante, PA-C, Victor Ferastraoaru, MD, Rajani Hanumanthu, MD, Sheryl Haut, MD, MS, Rana Jehle, PA-C, Isaac Molinero, MD, Lindsay Rick, LPN, Jillian Rosengard, MD, Mohamad Saifeddine, MD, William Sugrue, MD, Solomon L. Moshé, MD, and Karen Ballaban-Gil, MD

Neurology: Clinical Practice April 2021 vol. 11 no. 2 e97-e101 doi:10.1212/CPJ.0000000000001028

\author{
Correspondence \\ Dr. Gursky \\ jgursky@montefiore.org
}

\begin{abstract}
\section{Objective}

To determine whether there is a disparity in access to telemedical care that may be a function of socioeconomic status, language, or other demographic factors during the peak of the coronavirus disease 2019 (COVID-19) pandemic at a highly affected urban center (Montefiore Medical Center) in Bronx, NY.
\end{abstract}

\section{Methods}

We retrospectively investigated potential patient characteristics that might be associated with an increased likelihood of receiving a telephone visit as opposed to a televideo visit for patients followed in the pediatric neurology, adult epilepsy, and general neurology practices at Montefiore Medical Center during the 30-day period starting April 2, 2020, at the peak of the COVID-19 pandemic in New York.

\section{Results}

We found that patients who had telephone encounters, as opposed to televideo encounters, were overall older, less likely to have commercial insurance, and more likely to have Medicaid. Among pediatric patients, a preferred language other than English was also associated with a higher proportion of telephone encounters. New patients in both the adult and pediatric groups were more likely to have televideo visits.

\section{Conclusions}

Our findings identify demographic factors, including age, insurance type, and language preference, which may play a role in access to televideo encounters among neurology patients in an urban center during the COVID-19 pandemic. We suggest several potential practice, institution, and communitybased interventions, which might further expand access to televideo care for neurology patients.

\section{MORE ONLINE}

COVID-19 Resources

For the latest articles, invited commentaries, and blogs from physicians around the world NPub.org/COVID19

With the onset of the coronavirus disease 2019 (COVID-19) pandemic and resultant social distancing guidelines, medical offices around the United States were posed with the difficult task of quickly adopting telemedicine as the primary means of outpatient medicine.

\footnotetext{
Comprehensive Einstein/Montefiore Epilepsy Center (JMG, AB, SE, VF, RH, SH, RJ, IM, JR, MS, WS, SLM, KB-G), Albert Einstein College of Medicine, Bronx, NY; Saul R. Korey Department of Neurology (JMG, AB, SE, VF, RH, SH, RJ, IM, LR, JR, MS, WS, SLM, KB-G), Albert Einstein College of Medicine, Bronx, NY; Isabelle Rapin Division of Child Neurology (SE, RJ, IM, LR, MS, SLM, KB-G), Albert Einstein College of Medicine, Bronx, NY; and Department of Pediatrics (SLM, KB-G), Albert Einstein College of Medicine, Bronx NY. 
As a whole, telephone encounters are felt to be inferior to televideo visits due to the inherent limitations on performing a comprehensive physical examination. ${ }^{1-3}$ Despite a newly implemented televideo platform, our institution noted that there remained a substantial proportion of ambulatory visits conducted exclusively via telephone, even when all patients were preferentially offered televideo visits. Montefiore Medical Center is located in the Bronx borough of New York City and services one of the most culturally and economically diverse populations in New York. ${ }^{4}$ Anecdotal reports from physicians at our institution raised concerns that many patients who refused televideo visits in favor of telephone encounters cited concerns including a lack of internet access or a video-capable device, inability to navigate technological equipment, or concerns regarding the need for translator services, which were not supported. These reports brought about the concern for a growing disparity in access to telemedical care that may be a function of socioeconomic status, language, or other demographic factors. For these reasons, we retrospectively investigated potential patient characteristics that might be associated with an increased likelihood of receiving a telephone only visit as opposed to a televideo visit. We hypothesized that that patients who had telephone visits would be on average older, primarily non-English speaking, and have lower socioeconomic status.

\section{Methods}

We conducted a retrospective observational review of telemedicine encounters by pediatric neurology, adult epilepsy, and general neurology practices at Montefiore Medical Center during the 30-day period starting April 2, 2020, at the peak of the COVID-19 pandemic in New York. Patients of all ages were included if they underwent a telephone or televideo neurology encounter. Telephone encounters were defined as an ambulatory encounter conducted exclusively via telephone communication. Televideo encounters were defined as an ambulatory encounter, which used a live video connection for communication during all or part of the encounter. An institution supported televideo platform was encouraged, but not required, as long as the televideo services used a live video connection using software or platforms that were not public facing and were otherwise compliant with CMS guidelines for telemedicine services under the applicable 1135 waiver. Face-to-face encounters were excluded, as these patients required office visits for various reasons, most commonly due to the need for a detailed neurologic examination or procedures such as infusions and injections. We collected demographic information including age, sex, visit type (telephone only or televideo), visit status as a new or existing (follow-up) patient, whether a language other than English was specified as the patient's preferred language, and insurance type.

\section{Statistical Analysis}

We calculated baseline characteristics for each group, including means and SDs and medians and interquartile ranges for continuous variables, and frequencies and percentages for categorical variables.

Demographics were compared between the telephone and televideo groups. Because the adult and pediatric groups, as defined by treatment by an adult vs pediatric neurologist, differed significantly in terms of age and composition of insurance types, these groups were analyzed separately. Pearson chisquare statistics were calculated for nominal variables, and the Mann-Whitney test was used for comparison of continuous variables. Statistics were run using SPSS v26.

\section{Standard Protocol Approvals, Registrations, and Patient Consents}

This study is a retrospective investigation, which was deemed to have minimal risk, and as such, the requirement for consent was waived. Our study was approved by the Institutional Review Board at Albert Einstein College of Medicine.

\section{Data Availability}

Anonymized data will be shared by request from any qualified investigator.

\section{Results}

Of 1780 telemedicine encounters identified during the study period, $1150(64.6 \%)$ were conducted via telephone only, and 630 (35.4\%) were televideo encounters. Pediatric neurology encounters encompassed $46 \%$ of the total encounters. Detailed group demographics can be found in table 1. Overall, pediatric patients had higher rates of televideo visits compared with adults $(38.3 \%$ vs $32.9 \%, p=0.02)$. A summary of telephone vs televideo group characteristics can be found in table 2 .

In the adult group, patients undergoing televideo encounters were significantly younger than those who had telephone encounters (median age 53 years, interquartile range [IQR] 31, range 18-91 years vs median age 59 years, IQR 24, range 21-92 years, $p=$ $0.001)$. Furthermore, adult patients who had televideo encounters were more likely to have commercial insurance $(39.4 \%$ vs $24.3 \%, p<0.001)$ and less likely to have Medicaid (30.3\% vs $47.8 \%, p<0.001)$. Adult patients who had televideo encounters were more likely to self-pay than patients with telephone encounters $(1.9 \%$ vs $0.5 \%, p<0.001)$, albeit total numbers of selfpay patients were low. There was a higher percentage of televideo encounters vs telephone encounters among new patients (17\% vs $1.4 \%, p<0.001)$ and a higher percentage of telephone encounters among follow-up patients ( $98.6 \%$ vs $83 \%, p<0.001)$. There were no statistically significant differences between televideo and telephone groups in the likelihood of having Medicare, citing a preferred language other than English, or by sex.

In the pediatric group, patients who had televideo encounters were younger than patients who had telephone encounters (median age 12 years, IQR 9.5, range 2 months-39 years vs median 13 years, IQR 8 , range 5 months -59 years, $p=0.001$ ) and more likely to have commercial insurance $(42.8 \%$ vs $29.1 \%, p=0.001)$. A significantly lower percentage of patients with televideo encounters had Medicaid insurance compared with patients who had telephone encounters (56.9\% vs $70.1 \%, p=0.001)$. Pediatric patients who had televideo encounters were less likely to list a preferred 
Table 1 Patient Demographics

\begin{tabular}{lll}
\hline & Pediatrics $(\mathrm{n}=818)$ & Adult $(\mathrm{n}=962)$ \\
\hline Mean age, $\mathbf{y}(\mathrm{SD})$ & $12.8 \pm 7.3$ & $56 \pm 17.9$ \\
\hline Median age, y (IQR) & $16(9)$ & $58(27)$ \\
\hline Male & $403(49 \%)$ & $389(40 \%)$ \\
\hline Non-English language & $188(23 \%)$ & $573(60 \%)$ \\
\hline New patient & $715(51 \%)$ & $163(17 \%)$ \\
\hline Existing patient & $74(9 \%)$ & $83(7 \%)$ \\
\hline Insurance type & $744(91 \%)$ & $999(93 \%)$ \\
\hline Medicare & $4(1 \%)$ & $404(42 \%)$ \\
\hline Medicaid & $532(65 \%)$ & $267(28 \%)$ \\
\hline Commercial & $281(34 \%)$ & $92(29 \%)$ \\
\hline
\end{tabular}

language other than English (14.1\% vs $28.5 \%, p<0.001)$. Finally, there was a higher percentage of televideo encounters vs telephone encounters among new patients $(22.4 \%$ vs $0.8 \%, p<0.001)$ and a higher percentage of telephone encounters vs televideo encounters among follow-up patients (99.2\% vs $77.6 \%, p<0.001)$. There were no significant differences between televideo and telephone groups in the likelihood of having Medicare, enrolling as self-pay, or by sex.

\section{Discussion}

Our data identified demographic differences between patients who underwent telephone vs televideo encounters during the COVID-19 pandemic in Bronx, NY, an underserved area of New York City. Our findings point to a potential underlying disparity in access to televideo care, with a tendency for patients who are older, who have Medicare or Medicaid, and who do not speak English as a primary language, to receive telephone visits instead of televideo visits.

Ambulatory encounters conducted exclusively via telephone, without the benefit of a live video connection, have noteworthy limitations. Most obviously, an encounter without a live video feed precludes the ability of a physician to perform a physical examination. Furthermore, without video, there is less opportunity for nonverbal communication, particularly body language and facial cues that might provide helpful insights during a neurologic evaluation. As such, televideo visits are evidently the preferred method for ambulatory telemedicine care over telephone visits, with the latter being used often as a sort of last resort to provide at least some level of care in patients who are otherwise unable to undergo televideo visits.

There are likely multiple factors, which are contributing to our findings. Recent data support the notion that older adult patients may have, on average, lower levels of technological literacy ${ }^{5,6}$ and are less likely to have home internet access ${ }^{7}$ and thus may feel less comfortable navigating the enrollment and login processes of certain televideo services. Younger adults and pediatric patients and their parents may thus be more likely to use televideo platforms due to overall higher levels of comfort and higher rates of digital access. Of interest, the tendency for higher rates of televideo visits among younger patients even within the pediatric population may point to a slight preference among parents with younger children to undergo the more comprehensive evaluation that a televideo visit offers compared with the preference of older children and/or their parents. Patients with public insurance, particularly Medicaid, may be less likely to have access to the required televideo equipment including a video capable device and high-speed internet access. Furthermore, patients who do not speak English as a primary language are likely to run into multiple barriers along the way, including difficulty in navigating televideo platforms, which were initially largely available exclusively in English, in addition to the need for interpreter services, which are not easily integrated into most televideo services without custom programming. Finally, new patients are likely to have a stronger preference for televideo visits over telephone visits and thus may feel more motivated to navigate the various barriers to obtaining such care.

Our study is limited in that it is retrospective and includes a relatively limited degree of demographic information. Although we make several assumptions such that age is likely to be associated with technological literacy in adult patients, and insurance status is associated with socioeconomic status among pediatric and adult patients, these factors are rudimentary measures at best. We could not directly analyze factors such as access to a high-speed internet connection, lack of a video capable device, technological literacy, or individual patient preference for telephone vs televideo visits. Furthermore, although there are likely physician-related factors, including, but not limited to, variation among physicians with regard to comfort level in operating televideo platforms for which we could not account, all physicians in our practice group were fully trained in the operation of televideo equipment and were regularly seeing patients in this manner. Although all patients were offered a televideo visit as the primary means for telemedicine visits during the study period, there exist many nonrandom factors that might influence a patient to choose one visit type over the other for which we could not account. Finally, we could not account for patients who did not access care at all during the study period, including patients who canceled appointments, did not complete appointments as scheduled, or who lacked an operating telephone. Notwithstanding these limitations, this study represents a large-scale examination of telemedicine in an urban care center during the COVID-19 pandemic and offers new insight into some of the factors that may play a role in access to televideo care during this public health crisis.

In conclusion, our findings point to a potential underlying disparity in access to televideo services among the diverse population in Bronx, NY. Targeted public health interventions 
Table 2 Characteristics of Patients Who Underwent Telephone Visits Compared With Patients Who Underwent Televideo Visits

\begin{tabular}{|c|c|c|c|}
\hline & Telephone & Video & $p$ Value \\
\hline Pediatrics & $505(61.7 \%)$ & $313(38.3 \%)$ & 0.02 \\
\hline Adults & $645(67.1 \%)$ & $317(32.9 \%)$ & \\
\hline Adults & Telephone $(n=645)$ & Televideo $(n=317)$ & $p$ Value \\
\hline Mean age, y & $58.7 \pm 17.5$ & $53.2 \pm 18.3$ & 0.001 \\
\hline Median age, y (IQR) & $59(24)$ & $53(31)$ & 0.001 \\
\hline Sex, male & $269(41.7 \%)$ & $120(37.9 \%)$ & 0.253 \\
\hline Non-English language & $114(17.7 \%)$ & $49(15.5 \%)$ & 0.389 \\
\hline New patient & $9(1.4 \%)$ & $54(17 \%)$ & $<0.001$ \\
\hline Existing patient & $636(98.6 \%)$ & $263(83 \%)$ & $<0.001$ \\
\hline Medicare & $177(27.4 \%)$ & $90(28.4 \%)$ & $>0.05$ \\
\hline Medicaid & $308(47.8 \%)$ & $96(30.3 \%)$ & $<0.001$ \\
\hline Commercial & $157(24.3 \%)$ & $125(39.4 \%)$ & $<0.001$ \\
\hline Self-pay & $3(0.5 \%)$ & $6(1.9 \%)$ & $<0.001$ \\
\hline Pediatrics & Telephone $(n=505)$ & Televideo $(n=313)$ & $p$ Value \\
\hline Mean age, y & $13.5 \pm 6.9$ & $11.6 \pm 7.6$ & 0.001 \\
\hline Median age, y (IQR) & $13(8)$ & $12(9.5)$ & 0.001 \\
\hline Sex, male & $249(49 \%)$ & $154(49 \%)$ & 0.977 \\
\hline Non-English language & $144(28.5 \%)$ & $44(14.1 \%)$ & $<0.001$ \\
\hline New patient & $4(0.8 \%)$ & $70(22.4 \%)$ & $<0.001$ \\
\hline Existing patient & $501(99.2 \%)$ & $243(77.6 \%)$ & $<0.001$ \\
\hline Medicare & $3(0.6 \%)$ & $1(0.3 \%)$ & 0.05 \\
\hline Medicaid & 354 (70.1\%) & $178(56.9 \%)$ & 0.001 \\
\hline Commercial & $147(29.1 \%)$ & $134(42.8 \%)$ & 0.001 \\
\hline Self-pay & $1(0.2 \%)$ & $0(0 \%)$ & $>0.05$ \\
\hline
\end{tabular}

including expansion of public programs to increase access to both high-speed internet access and video capable devices may ensure that financial factors do not preclude patients from having full access to televideo services during emergency situations and beyond. Expansions of multilanguage support and interpreter services into televideo platforms are likewise necessary. Within physician practices, an opportunity to increase the uptake of televideo visits likely exists at the point of first contact, when patients are being scheduled for their appointments. Scheduling staff should be trained and equipped to assist patients, particularly those who are older, have Medicare/ Medicaid, or are non-English speaking, in navigating the practice's televideo system. Interventions could include dedicated staff who can run a test visit with patients over the video platform to ensure that they understand how to use the software and are ready for their appointments in advance. Finally, patient liaisons offering real-time technical support may be needed to assist patients who lack the technological literacy to navigate televideo platforms. Further research is needed to delineate the extent of disparities in access to televideo neurology care and investigations regarding possible differences in the outcomes and satisfaction among patients who use telephone visits without video.

\section{Acknowledgments}

The authors acknowledge with gratitude the administrative staff of the Neurology Department for their excellent technical expertise and dedication to patients' care during the COVID-19 pandemic.

\section{Study Funding}

No targeted funding reported. 


\section{TAKE-HOME POINTS}

$\rightarrow$ Televideo visits offer the opportunity for a more comprehensive neurologic evaluation compared with telephone-only visits.

$\rightarrow$ There may exist disparities in access to televideo neurology care as a function of age, socioeconomic status, and spoken language.

$\rightarrow$ Targeted interventions at the physician practice, institution, and community level should be developed to minimize any developing disparities in access to televideo neurology care.

\section{Disclosure}

J. Gursky, A. Boro, S. Escalante, V. Ferastraoaru, and R. Hanumanthu report no disclosures. S. Haut is a member of the editorial board of Epilepsy \& Behavior. She has received consultant fees from Alden Health. R. Jehle, I. Molinero, L. Rick, J. Rosengard, M. Saifeddine, and W. Sugrue report no disclosures. S.L. Moshé is serving as Associate Editor of Neurobiology of Disease and is on the editorial board of Brain and Development, Pediatric Neurology and Physiological Research. He receives from Elsevier an annual compensation for his work as Associate Editor in Neurobiology of Disease and royalties from 2 books he coedited. He has received consultant fees from UCB and Pfizer. K. Ballaban-Gil reports no disclosures. Full disclosure form information provided by the authors is available with the full text of this article at Neurology.org/cp.

\section{Publication History}

Received by Neurology: Clinical Practice August 27, 2020. Accepted in final form November 6, 2020.

\section{Appendix Authors}

\begin{tabular}{lll}
\hline Name & Location & Contribution \\
\hline Jonathan Gursky, MD & $\begin{array}{l}\text { Bronx, } \\
\text { NY }\end{array}$ & $\begin{array}{l}\text { Designed and conceptualized the } \\
\text { study; analyzed and interpreted the } \\
\text { data; and drafted and revised the } \\
\text { manuscript for intellectual content }\end{array}$ \\
\hline Alexis Boro, MD & Bronx, & $\begin{array}{l}\text { Major role in the acquisition of data } \\
\text { and revised the manuscript for } \\
\text { intellectual content }\end{array}$ \\
\hline
\end{tabular}

Appendix (continued)

\begin{tabular}{|c|c|c|}
\hline Name & Location & Contribution \\
\hline Sheri Escalante, PA-C & $\begin{array}{l}\text { Bronx, } \\
\text { NY }\end{array}$ & $\begin{array}{l}\text { Major role in the acquisition of data } \\
\text { and revised the manuscript for } \\
\text { intellectual content }\end{array}$ \\
\hline $\begin{array}{l}\text { Victor Ferastraoaru, } \\
\text { MD }\end{array}$ & $\begin{array}{l}\text { Bronx, } \\
\text { NY }\end{array}$ & $\begin{array}{l}\text { Major role in the acquisition of data, } \\
\text { analyzed and interpreted the data, and } \\
\text { revised the manuscript for intellectual } \\
\text { content }\end{array}$ \\
\hline $\begin{array}{l}\text { Rajani Hanumanthu, } \\
\text { MD }\end{array}$ & $\begin{array}{l}\text { Bronx, } \\
\text { NY }\end{array}$ & $\begin{array}{l}\text { Major role in the acquisition of data } \\
\text { and revised the manuscript for } \\
\text { intellectual content }\end{array}$ \\
\hline Sheryl Haut, MD, MS & $\begin{array}{l}\text { Bronx, } \\
\text { NY }\end{array}$ & $\begin{array}{l}\text { Major role in the acquisition of data } \\
\text { and revised the manuscript for } \\
\text { intellectual content }\end{array}$ \\
\hline Rana Jehle, PA-C & $\begin{array}{l}\text { Bronx, } \\
\text { NY }\end{array}$ & $\begin{array}{l}\text { Major role in the acquisition of data } \\
\text { and revised the manuscript for } \\
\text { intellectual content }\end{array}$ \\
\hline Isaac Molinero, MD & $\begin{array}{l}\text { Bronx, } \\
\text { NY }\end{array}$ & $\begin{array}{l}\text { Major role in the acquisition of data } \\
\text { and revised the manuscript for } \\
\text { intellectual content }\end{array}$ \\
\hline Lindsay Rick, MD & $\begin{array}{l}\text { Bronx, } \\
\text { NY }\end{array}$ & $\begin{array}{l}\text { Major role in the acquisition of data } \\
\text { and revised the manuscript for } \\
\text { intellectual content }\end{array}$ \\
\hline Jillian Rosengard, MD & $\begin{array}{l}\text { Bronx, } \\
\text { NY }\end{array}$ & $\begin{array}{l}\text { Major role in the acquisition of data } \\
\text { and revised the manuscript for } \\
\text { intellectual content }\end{array}$ \\
\hline $\begin{array}{l}\text { Mohamad Saifeddine, } \\
\text { MD }\end{array}$ & $\begin{array}{l}\text { Bronx, } \\
\text { NY }\end{array}$ & $\begin{array}{l}\text { Major role in the acquisition of data } \\
\text { and revised the manuscript for } \\
\text { intellectual content }\end{array}$ \\
\hline William Sugrue, MD & $\begin{array}{l}\text { Bronx, } \\
\text { NY }\end{array}$ & $\begin{array}{l}\text { Major role in the acquisition of data } \\
\text { and revised the manuscript for } \\
\text { intellectual content }\end{array}$ \\
\hline $\begin{array}{l}\text { Solomon L. Moshé, } \\
\text { MD }\end{array}$ & $\begin{array}{l}\text { Bronx, } \\
\text { NY }\end{array}$ & $\begin{array}{l}\text { Designed and conceptualized the } \\
\text { study and revised the manuscript for } \\
\text { intellectual content }\end{array}$ \\
\hline $\begin{array}{l}\text { Karen Ballaban-Gil, } \\
\text { MD }\end{array}$ & $\begin{array}{l}\text { Bronx, } \\
\text { NY }\end{array}$ & $\begin{array}{l}\text { Designed and conceptualized the study, } \\
\text { analyzed the data, major role in the } \\
\text { acquisition of data, and revised the } \\
\text { manuscript for intellectual content }\end{array}$ \\
\hline
\end{tabular}

\section{References}

1. Fesler JR, Stanton S, Merner K. Bridging the gap in epilepsy care: A single-center experience of 3700 outpatient tele-epilepsy visits. Epilepsia 2020;61:e95-e100.

2. Hatcher-Martin JM, Adams JL, Anderson ER, et al. Telemedicine in neurology: telemedicine work group of the American Academy of neurology update. Neurology 2020;94:30-38.

3. Capampangan DJ, Wellik KE, Bobrow BJ, et al. Telemedicine versus telephone for remote emergency stroke consultations: a critically appraised topic. Neurologist 2009;15:163-166.

4. González-Corzo M, Vassilios G. The Bronx today: a comparative socioeconomic profile. J Latino/Latin Am Stud 2012;4:79-97.

5. McKee H, Blair K. Older adults and community-based technological literacy programs: barriers \& benefits to learning. Community Literacy J 2006;1:13-39.

6. Lam K, Lu AD, Shi Y, Covinsky KE. Assessing telemedicine unreadiness among older adults in the United States during the COVID-19 pandemic. JAMA Intern Med 2020; 180:1389-1391.

7. Roberts ET, Mehrotra A. Assessment of disparities in digital access among Medicare beneficiaries and implications for telemedicine. JAMA Intern Med 2020;180:1386-1389. 


\title{
Neurology ${ }^{\circ}$ Clinical Practice
}

\author{
Disparities in Access to Neurologic Telemedicine During the COVID-19 Pandemic: A \\ Bronx Tale \\ Jonathan M. Gursky, Alex Boro, Sheri Escalante, et al. \\ Neurol Clin Pract 2021;11;e97-e101 Published Online before print December 3, 2020 \\ DOI 10.1212/CPJ.0000000000001028
}

This information is current as of December 3, 2020

Updated Information \&
Services
References
Citations
Subspecialty Collections

Subsecialty Collections

Permissions \& Licensing

Reprints including high resolution figures, can be found at:

http://cp.neurology.org/content/11/2/e97.full.html

This article cites 7 articles, 0 of which you can access for free at: http://cp.neurology.org/content/11/2/e97.full.html\#\#ref-list-1

This article has been cited by 4 HighWire-hosted articles: http://cp.neurology.org/content/11/2/e97.full.html\#\#otherarticles

This article, along with others on similar topics, appears in the following collection(s):

Advocacy

http://cp.neurology.org//cgi/collection/advocacy

COVID-19

http://cp.neurology.org//cgi/collection/covid_19

Health disparities

http://cp.neurology.org//cgi/collection/health_disparities

Inclusion, Diversity, Equity, Anti-racism, and Social Justice (IDEAS)

http://cp.neurology.org//cgi/collection/all_equity_diversity_and_inclusi on

Structural and social determinants of health

http://cp.neurology.org//cgi/collection/structural_social_determinants

Information about reproducing this article in parts (figures,tables) or in its entirety can be found online at:

http://cp.neurology.org/misc/about.xhtml\#permissions

Information about ordering reprints can be found online:

http://cp.neurology.org/misc/addir.xhtml\#reprintsus

Neurol Clin Pract is an official journal of the American Academy of Neurology. Published continuously since 2011, it is now a bimonthly with 6 issues per year. Copyright $\odot 2020$ American Academy of Neurology. All rights reserved. Print ISSN: 2163-0402. Online ISSN: 2163-0933.

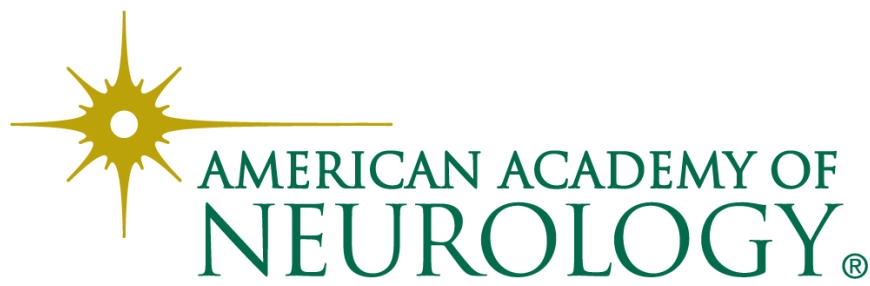

